\title{
問診方式一第一報一
}

一新自動問診装置による問診方式とその評価一

井上 進 ${ }^{1)}$ 堺 義幸 ${ }^{1)}$ 大村 憲治2) 山田 敏一2)

坂崎 富夫 ${ }^{3)}$ 幡生 寛人 ${ }^{3)}$

共同発表者である坂崎診療所では会員精密健診, 各 種ドックコース，成人病健診，定期健康診断等多種の 健診コースを実施される。問診方式も OCR, 対話型等 多様ある。

1. 主な目的

1）受診者自身が対話形式で容易に回答可能。

2）回答内容は質問内容に応じて可変。

3）問診内容の追加，変更可能。

4）問診結果は診断な生活指導に活用可能。

5）健診コースに応じた問診コースの追加可能。

6) 健診コース, 受診回数等により問診内容, 問診数 等が可変。

2. 構成

2.1)ハードウェア構成：パソコン, 14 カラー CRT, タッチスクリーン，カードリーダ付コントロー ラ

2.2)ソフトウェアモジュール構成：初期画面，問診 内容(コース)，問診結果管理，問診回答，最終 画面，結果出力，格納等各種処理。出来得る限 りテーブル化。回答分岐方式の採用。

2.3 ) 表示領域の分類：14 カラーCRT とタッチスク リーンにより質問内容表示，回答枠，誤り表示 等領域を分類し同一画面に纒めた。各表示領域 はカラーで色分。見易さと誤り削減。

3. 問診内容グループ分類

A : スポーツ度

B：A 型行動パターン

C：食事 1

D：食事 2

\section{A New Method and Evaluation for Automatic Medical}

\section{History Talker}

島津製作所

1) 医用機器事業部

2）情報システム部

3）坂埼診療所
$\mathrm{E} ：$ ストレス耐性度

$\mathrm{F}$ : 健康生活チェック

$\mathrm{G}$ ：ストレス評価

$\mathrm{H}$ : 肉体的疾患

肉体的疾患には呼吸器, 循環器, 消化器等 12 分類。 分類ごとで数種類の問診有り。

4. 動作

1）受診カードをカードリーダにセットすると,第 1 問目の質問と回答が表示される。

所定の回答枠に軽くタッチするだけで問診が進めら れる。

2）問診結果はコントローラを介してホスト CPU へ伝送する。

\section{5. 問診結果}

択一の質問：回答内容の要約とその得点を出力。 Yes, No 質問 : 質問内容の要約と $\mathrm{Y}, \mathrm{N}, \mathrm{O}$ 等を出力。 評価欄：総合得点により評価分類し文言を出力。

6. まとめ

6.1 ) 評価：約 1 年間使用結果次の評価を得た。

1) 操作性が飛躍的に向上。

2) 健診コース等より問診コース可変容易。

3) 問診内容, 回答内容等変更容易。

4) 評価に基づき生活指導への活用容易。

$6.2)$ 今後の検討課題
1)メディカル診断と活用効果の検討。
2)体力診断との相関関係の検討。
3)健康増進への指示と追跡。
4)結果の集計による総合評価の検討。 